
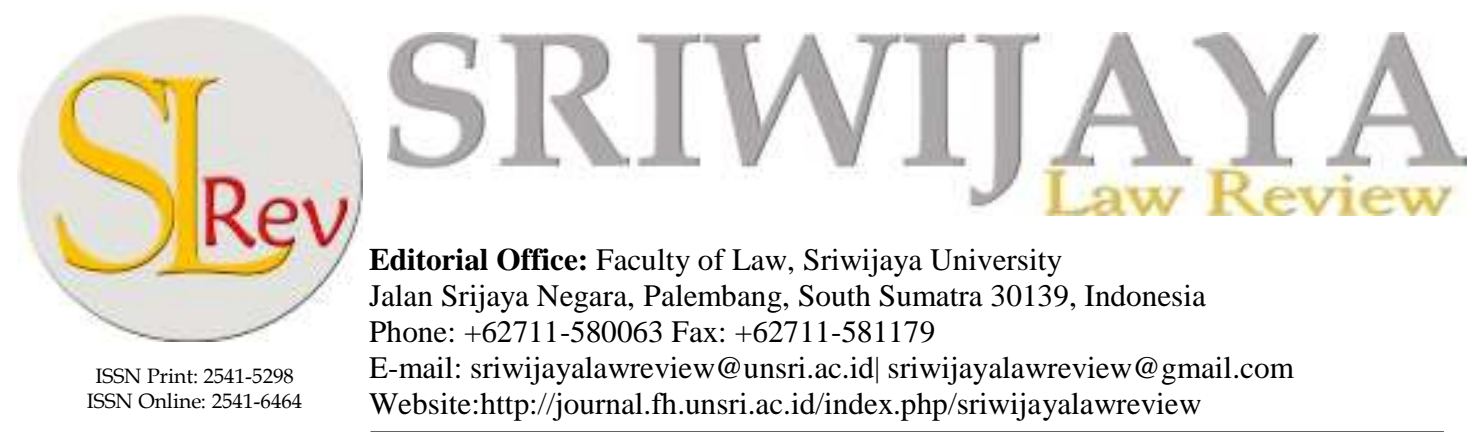

Editorial Office: Faculty of Law, Sriwijaya University

Jalan Srijaya Negara, Palembang, South Sumatra 30139, Indonesia

Phone: +62711-580063 Fax: +62711-581179

E-mail: sriwijayalawreview@unsri.ac.id|sriwijayalawreview@gmail.com

Website:http://journal.fh.unsri.ac.id/index.php/sriwijayalawreview

\title{
The Legal Conundrum in the Implementation of the Convention on the Rights of the Child in Nigeria
}

\author{
Ibrahim Danjuma $^{\mathrm{a}}$ and Karatu Afabwaje Joel ${ }^{\mathrm{a}}$
}

a Faculty of Law, Bauchi State University Gadau, Nigeria. E-mail: idanjuma27@gmail.com.

\begin{tabular}{|c|c|}
\hline Article & Abstract \\
\hline $\begin{array}{ll}\text { Keywords: } & \\
\text { Children's } & \text { Rights; } \\
\text { Domestication; } & \\
\text { Enforceability; } & \text { State } \\
\text { Responsibility. } & \end{array}$ & $\begin{array}{l}\text { International law or treaty binds a state where such state signed, ratified } \\
\text { acceded or domesticated same. In a monist State, ratification alone suffices } \\
\text { for the international law or treaty to become binding whereas, in a dualist } \\
\text { State, domestication as a condition must have complied. It is because of the } \\
\text { peculiarities within various nations' legal systems (Monist or Dualist } \\
\text { system). In 1989, The United Nations Convention on the Rights of the Child } \\
\text { (UNCRC), an international human rights instrument came into force. Since } \\
\text { its domestication as the Child Rights Act (CRA 2003) in Nigeria by the } \\
\text { National Assembly, only about } 24 \text { States have enacted the law for onward } \\
\text { enforcement. Nigeria is a nation which became independent in the year } 1960 \\
\text { comprising now of } 36 \text { states and Abuja as its Federal Capital Territory all } \\
\text { under the Federal Government. Since its domestication as the Child Rights } \\
\text { Act (CRA 2003) in Nigeria by the National Assembly, many States have } \\
\text { enacted the law for onward enforcement. However, few states are yet to } \\
\text { comply and raise a question as to whether the said CRC has a binding force } \\
\text { in all the States of the Federation. This study aims to examine the extent of } \\
\text { how the UNCRC and CRA are being enforced in Nigeria. This study's } \\
\text { research methodology is purely doctrinal, where library materials such as } \\
\text { books, articles from journals, and online articles have been carefully selected } \\
\text { and analyzed for this research. This paper recommends establishing a global } \\
\text { agency or organ that should be saddled with the responsibility of ensuring } \\
\text { full compliance and enforcement of international laws or treaties. }\end{array}$ \\
\hline \multicolumn{2}{|c|}{$\begin{array}{l}\text { (0)2021; This is an Open Access Research distributed under the term of the Creative Commons Attribution } \\
\text { License (https://Creativecommons.org/licences/by/4.0), which permits unrestricted use, distribution, and } \\
\text { reproduction in any medium, provided the original works is properly cited. }\end{array}$} \\
\hline
\end{tabular}

\section{INTRODUCTION}

The massive destruction of lives and properties after the Second World War and the dire need to protect human life led to the enactment of various human rights instruments such as the Universal Declaration of Human Rights (UDHR 1948), International Covenant on Civil and Political Rights (ICCPR 1966); International Covenant on Economic, Social and Cultural Rights (ICESCR 1966); Convention Against Torture (CAT 1987) among others. Basically, Child Rights 
is said to have evolved following the development of human rights and the need to protect children's interest. The United Nations Convention on the Rights of a Child (UNCRC) was enacted in 1989 and ratified by many countries. Consequently, Nigeria signed and ratified the UNCRC and domesticated the same and tagged it as Child Rights Act (CRA) in 2003.

The above development is predicated upon the fact that for any International law to have any force of law in Nigeria, it must be subjected to the provisions of Nigeria's constitution. It means that any law that does not meet up with the requirement(s) of the Nigerian constitution shall be void. The UNCRC is an international treaty that is derived from the UDHR. ${ }^{1}$ For the UNCRC to have the force of law in Nigeria, the Nigerian constitution must have passed the test set out. ${ }^{2}$ Section 12 the Nigerian constitution provides "no treaty between the Federation and any other country shall have the force of law except to the extent to which any such treaty has been enacted into law by the National Assembly". From the preceding, the condition set out by the constitution of Nigeria is that the National Assembly must enact an International Law before it can have the force of law, hence, the legal basis for CRA's enactment in 2003. As at 2009 since 2003 when the CRA was enacted, 21 states had enacted the CRA as a law. Some of these states include Lagos, Enugu, Kogi, Nassarawa, Kaduna, Abia, Kwara, Osun, e.t.c. ${ }^{3}$ Nevertheless, as of 2019, only about 11 states have yet to enact the CRA as a law. These states include Bauchi, Yobe, Kano, Sokoto, Adamawa, Borno, Zamfara, Kebbi, Katsina and Jigawa. ${ }^{4}$

What is not clear from the constitution is whether after such enactment or domestication of the National Assembly's law, does it bind other States of the federation? Another problem with the implementation and enforcement of International law is the absence of adequate apparatus for the enforcement of International law in the States of the federation.

With the attention and protection given to human rights after World War II, one would be curious about the delay in adopting and enacting the Child Rights Act as a State law in the few states that are yet to make the law. Additionally, there is yet to be full implementation of the Child Rights Act in some states that have enacted the same. These States are yet to prosecute cases on violation of Child's rights. Can the domestication of the UNCRC by the National Assembly suffice the implementation of the Convention in all Nigeria's states federation? Basically, States would find it difficult to fully implement the UNCRC as it is an International law and considering that Nigeria practices a federal government system. What is the practicability of the full implementation of the UNCRC or CRA in Nigeria? These issues, among others, are some of the legal problems to be addressed in this study.

This study focuses on the status of the UNCRC and CRA in Nigeria, the extent of their enforcement/ implementation in Nigeria, suggesting possible means for notable success in the implementation of the UNCRC and CRA for the protection of the best interest of a child. In identifying the legal problems and recommending possible solutions, the researchers discuss the differences between International law and International instruments, ratification and

Hurst Hannum, “The UDHR in National and International Law," JSTOR 3, no. 2 (1998): 144-58.

2 C. J. S. Azoro, "The Place of Customary International Law in the Nigerian Legal System-A Jurisprudential Perspective," International Journal of Research (IJR) 1, no. 3 (2020).

3 Geofrey Njoku and Sharon Oladiji, "Calling on 15 States Left to Protect Their Children," Allafrica, 2009.

4 Premium Times. 202011 States yet to domesticate Child Rights Act- Minister. Available from: https://www.premiumtimesng.com/news/top-news/420620-11-states-yet-to-domesticate-child-rights-actminister.html [retrieved: December 24, 2020 at 18:45]. 
domestication of International law, the Nigerian legal system and its dualistic nature, the UNCRC, CRA and the factors responsible for the non and/or low implementation of the UNCRC and the CRA in Nigeria.

\section{ANALYSIS AND DISCUSSION \\ International Laws and International Legal Instruments}

International law is an organized system of treaties and agreements entered into by two or more nations of the world that such a treaty or agreement governs how nations interact with each other, how citizens interact with each other, and how businesses are carried out among nation(s). ${ }^{5}$ International law is also known as public international law is the set of rules, norms, and standards generally accepted by nations to govern their social, political, economic relations. ${ }^{6}$ It establishes normative guidelines and a common conceptual framework to guide States across a broad range of domains, particularly on war, diplomacy, trade, and human rights, e.t.c. International law allows for the practice of a stable, consistent, and an organized international relation among nation(s) of the world. Some international law sources include international custom (general state practise accepted as law), treaties, and general principles. International law is quite different from a state or national law in that it is primarily applicable to countries rather than individuals. It also operates through consent, i.e. (acceptance, adoption, ratification and/or domestication) since there is no universally accepted authority to enforce it upon sovereign States. Consequently, States may choose not to abide by International law, and even break a treaty. However, such violations, exceptionally customary international law and peremptory norms, can be met with coercive actions ranging from military intervention to diplomatic and economic pressure. ${ }^{7}$

On the other hand, international instruments are instruments that any State in the world can become a party to, for example, the Charter of the United Nations and International Criminal Law. ${ }^{8}$ International instruments can further be described as established forms of broad foundations for protecting nations, entities and persons from harmful practices. Other examples of International instruments include the Universal Declaration of Human Rights (1948) which provides in Article 1 and 3 that all humans are born free, equal, and with dignity. As such, non shall be subjected to torture, inhumane, cruel or degrading treatment. There is also the ICCPR 1966, Convention of the Elimination of All Forms of Discrimination Against Women (CEDAW 1979), United Nations Convention on the Rights of a Child (UNCRC 1989) and other related conventions. $^{9}$

5 Find Law. 2016 What is International Law. Available from: https://www.findlaw.com/hirealawyer/internationallaw.html [retrieved: December 24, 2020].

6 Find Law.

7 Find Law.

8 Iceladic Human Rights Centre. International Law Instruments. Available from: https://www.humanrights.is/en/human-rights-education-project/human-rights-instruments/internationational-lawinstruments [retrieved: October 02, 2019].

9 UN WOMEN, “Overview and International Legal Instruments," 2020, www.endvawnow.org/en/articles/582overview-and-international-legal-instruments.html [retrieved: December 24, 2020]. 
Furthermore, International instruments are the treaties and other international texts that generally serve as a legal source for International laws. ${ }^{10}$ International instruments can be divided into two, i.e. international instruments to which any state in the world can be a party to and regional instruments restricted to states in a particular region of the world, e.g. Africa, Asia, West Africa e.t.c. ${ }^{11}$

\section{Ratification or Domestication?}

Ratification is the confirmation of an act of another person. ${ }^{12}$ Ratification is an approval of an act of an agent that lacked the authority to bind the principal legally. To ratify a treaty, the State first signs it and then carries out its own established national legislative requirements. ${ }^{13}$ Once the appropriate national organ makes a formal decision to be a party, ratification is said to be done. The ratification instrument is a formal sealed letter referring to the decision or choice which is signed by the state's appropriate authority. ${ }^{14}$

Article 2 (1) (b) of the Vienna Convention on the Law of Treaties (VCLT 1969) provides that "ratification', 'acceptance', 'approval' and 'accession' mean in each case the international Act whereby a State establishes at the international plane its consent to be bound by a treaty". ${ }^{15}$

Domestication in International law is a process when an International agreement becomes a part of the municipal law of a state. For International law or treaty to affect, the country must pass domestic legislation. In some states categorized as monist, treaties which are considered to be sufficient become law without passing a domestic legislation ${ }^{16}$ while a dualist require domestic legislation to adopt such International Agreement after ratification. There are cases where treaties may enter into force immediately upon signature and binds the parties without ratification. It usually occurs in bilateral treaties. This principle was firmly established by the International Court of Justice in the case of Cameroon v. Nigeria. ${ }^{17}$

On 29 March 1994, Cameroon brought an application before the International Court of Justice (ICJ) seeking the court to determine the question of sovereignty on the Bakassi Peninsula as well as a parcel of land around Lake Chad against Nigeria. ${ }^{18}$ Cameroon also brought other demands which include a declaration of the maritime boundary between the two states, the instant and absolute retraction of Nigerian troops and properties from that area according to the fact that Nigeria had violated and was violating the fundamental principles of respect for frontiers inherited from colonization, i.e. uti possidetis which means "as you possess under the law".

10 O A. Hathaway “Do Human Rights Treaties Make a Difference?”, The Yale Journal Vol. 111, No. 8 (Jun., 2002, pp. 1935-2042 (108 Pages) (The Yale Law Journal Company, Inc.) https://doi.org/10.2307/797642.

11 O A. Hathaway.

12 Domestication and Ratification of International Law. Available from: https://www.duhaime.org/Legal/I/InternationalLaw.aspx[retrieved: October 02, 2019 at 22:15].

${ }^{13}$ EU Law Glossary, When a Dualist State Signs a Treaty, the Treaty Becomes Binding Only If It Is Incorporated by a Domestic Statute (Oxford University Press, 2008).

14 Treaty Reference Guide Clarendon Pres, Oxford, and United Nations Treaty Collection, Definition of Key Terms, 1999, http://untreaty.un.org/guide/asp.

15 "The 1969 Vienna Convention on the Law of Treaties, Article 2 (1) (B)" (n.d.).

16 Anthony Aust, Domestication of International Law Modern Treaty Law and Practice (Cambridge University Press, 2019).

17 "Cameroon v Nigeria 2002 ICJ Reports (Boundary Dispute between Cameroon and Nigeria on Land and Maritime)," n.d.

18 D. D Caron, "Land and Maritime Boundary between Cameroon and Nigeria 2002," American Journal of International Law, n.d., http://www.icj-cj.org. 
It is simply a principle of International law that provides that newly formed sovereign states retain the internal borders that their preceding dependent area had before their independence ${ }^{19}$ and the rules of conventional and customary international law, and that Nigeria's international responsibility was not complied with. ${ }^{20}$

Nigeria came up with about seven (7) preliminary objections to the suit in June 1998, but the same was rejected. Some of the preliminary objections were that the court lacked jurisdiction and that Cameroon's application was inadmissible. Nigeria also laid claims on the disputed Lake Chad area based on historical consolidation of title, i.e. presence/ usage of land over a reasonable period and Cameroon's acquiescence or tacit consent and as such preference should be given to the holder of the title. ${ }^{21}$

As per the court's jurisdiction, Cameroon relied on the declarations made between Cameroon and Nigeria under Article 36(2) of the ICJ Statute. In the court's judgment of 11 June 1998, the court rejected some of Nigeria's preliminary objections, and it also reserved some for consideration at the merit stage..$^{22}$

Consequently, the court rejected Nigeria's argument that the Maroua Declaration ${ }^{23}$ was invalid under International law even though it was signed by the Nigerian Head of State of the time, but it was never ratified. From the above, it is clear that an International law can become binding on a state upon signature regardless of whether ratification or domestication has been done. However, it is worthy of note that this position of the law is dependent on the circumstances of a case. ${ }^{24}$

Thus, ratification is an act of the executive arm of the government at the international level. At the same time, domestication is primarily done by the legislature and is meant to bring the treaty into the domestic setting.

\section{The Nigerian Legal System}

A Legal System refers to the process of making, interpreting and enforcing the law of a state. ${ }^{25}$ According to Ese Malemi, the legal system refers to the laws, courts personnel of the law, and the justice system's administration in a given state, country or geographical entity. Therefore, a legal system comprises four basic elements that include the laws, courts, personnel of the law and the administration of Justice System. ${ }^{26}$

The amalgamation of the Northern and Southern Protectorates in 1914 by Great Britain gave birth to the present-day Nigeria. ${ }^{27}$ Before the coming of the colonial masters, Nigerians existed as

9 D. D Caron

D. D Caron, "Land and Maritime Boundary between Cameroon and Nigeria 2002."

D. D Caron.

D. D Caron.

The bilateral treaty between Cameroon and Nigeria was referred to as the Maroua Declaration

24 C.E. Okeke and M.I. Anushiem, "Implementation of Treaties in Nigeria: Issues, Challenges and the Way Forward," Nnamdi Azikiwe University Journal of International Law and Jurisprudence 9, no. 217 (2018).

25 US Legal, "Legal System Law and Legal Definition,” uslegal.com, 2019.

26 Ese Malemi, Nigerian Legal System, 3rd ed., 1999.

27 Daniels. A. F, "Historical Survey of Amalgamation of the Northern and Southern Police Departments of Nigeria in 1930," European Scientific Journal 8, no. 18 (2011). 
a people of different, independent and unrelated entities ${ }^{28}$ as each of the occupants had their own Systems of Legislative, Judicial and Executive Administration. ${ }^{29}$

The system of government adopted and practised in Nigeria is Federalism. A federal system of government is a system where powers are shared between the central and regional governments. In Nigeria, power is shared between the federal, state and local governments. The constitution adequately distinguishes the responsibilities between these three levels of government into the exclusive, concurrent and residual list. Where there is a clash or conflict between the levels of government, the Federal shall prevail over the state, and likewise, the state over the Local Government and such law or action by the lower level of government shall be void. ${ }^{30}$ The Nigerian legal system sources include Customs and Traditions, Islamic law, English law, Local Legislations, Foreign laws and Legal Writings from erudite renowned scholars of the various classes of law. ${ }^{31}$

\section{The Dualistic Nature of the Nigerian Legal System}

In Nigeria, there exist two law making bodies which include the National Assembly ${ }^{32}$ for the whole federation of Nigeria and the State Houses of Assembly ${ }^{33}$ for each respective States of the federation. The various State Houses of Assembly make laws which are peculiar to the people of such state. Where the National Assembly makes a law, it remains an option to adopt the same before implementation and enforcement. It is at the discretion of such state to decide whether they want such law or not. This dual system is one of the factors responsible for the nonimplementation and/or non-enforcement of specific laws in individual States made by the National Assembly in Nigeria. Nigeria's dualistic legal system is one of the basic reasons responsible for the challenge in the implementation and enforcement of the UNCRC/ CRA in Nigeria.

\section{The United Nations Convention on the Rights of the Child}

In 1989, a notable contribution was made to protect children's rights through the enactment and adoption of the United Nations Convention on the Rights of the Child (UNCRC 1989). The Convention separated adulthood from childhood. Childhood is a particular time in which children should grow, play, develop, learn, and flourish with dignity. ${ }^{34}$ The UNCRC is a human rights treaty that sets out to protect children's civil, political, economic, social, health and cultural rights. ${ }^{35}$

28 U S Abbo and Others Umar Alkali, "Nature and Sources of Nigerian Legal System: An Exorcism of a Wrong Notion," International Journal of Economics, Law and Business 5, no. 4 (2014): 1-10.

29 Tobi N, Sources of Nigerian Law, ed. U S Abbo and Others Umar Alkali (Internatio (Lagos: M.J. Professional Publishers Ltd, 1996).

30 Tobi N.

31 Tobi N.

32 Tobi N. S 47 which provides that there shall be a National Assembly for the federation which shall consist of a Senate and a House of Representatives.

33 Tobi N. S 90 which provides for each state in the federation a House of Assembly

34 Premium Times 2019. Why every Nigerian state must domesticate, implement Child Rights Act. Available from: https://www.premiumtimesng.com/health/health-features/336790- why-every-nigerian-state-must-domesticateimplement-child-rights-act.html [retrieved: December 23, 2020].

35 UNICEF. The 1989 United Nations Convention on the Rights of a Child. Available from: https://www.unicef.org/child-rights-convention/what -is-the-convention [retrieved: December 24, 2020 at 09:13 am]. 
The Convention ${ }^{36}$ provides that any person below the age of eighteen (18) years is a child until the majority is attained. The Black's Law Dictionary ${ }^{37}$ defines a child as a person under the age of majority. The age of majority has since been seen as age eighteen (18). The African Union Charter on the Rights of Women and Children (ACURWC) defines a child as "every human being below the age of eighteen (18) years".

The issue of a child's rights before the enactment of the UNCRC was locked up in jurisprudential debate among scholars and human rights activist until the UNCRC. ${ }^{38}$ The grave atrocities committed during World War II and other factors necessitated human rights thoughts and decided to ensure international unity. ${ }^{39}$ On the above, efforts were made to establish a legal and administrative set up to protect children's rights. Consequently, the UN adopted the Declaration of Geneva ${ }^{40}$ for the protection of a child in 1924. It was subsequently followed in 1945 by the United Nations Charter of Universal Declaration of Human Rights (UDHR 1948). ${ }^{41}$ The actual regime to protect a child came with the adoption of the 1959 Declaration on the Rights of the Child by the United Nations. The UNCRC was drafted in 1979, which is referred to as the Year of the Child. In 1989, the UNCRC was adopted and on 02 September 1990, it came into force. It became the most undemanding document on child rights having the highest number of ratifications in international instruments' history ratification. ${ }^{42}$ More than 196 countries are party to it, including every United Nations member except the United States. ${ }^{43}$

The Convention is to ensure the exercise of parental responsibilities within States and also to serve as a legislation against human trafficking, child slavery, child prostitution and pornography among others as it forbids children from being separated from parents against their will except where it is in the best interest of the child. ${ }^{44}$ In the case of Williams $v$ Williams ${ }^{45}$ the court described a child's interest to comprise of many factors for consideration such as emotional attachment to the particular parent (mother or father), adequacy of facilities such as educational, religious or opportunities for proper upbringing.

\section{The Child Rights Act in Nigeria}

The UNCRC is a human rights treaty setting out the civil, cultural, social, economic, health and political rights children are entitled to. In 2003, Nigeria domesticated the UNCRC as the Child Rights Act through a due recognized process based on Section 12 of the Nigerian constitution

36 "United Nations Convention on the Rights of a Child 1989 Part 1 Art 1" (n.d.).

7 B.N. Garner, The Black's Law Dictionary, 8th ed. (West Group, St Paul MINN, 2004).

${ }^{38}$ Okpalaobi \& Ekwueme, United Nations Convention on the Rights of a Child: Implementation of Legal and Administrative Measure in Nigeria (NAUJILI, 2015).

39 Okpalaobi \& Ekwueme.

40 Cynthia Price Cohen, "The Role of Nongovernmental Organizations in the Drafting of the Convention on the Rights of the Child," Human Rights Quarterly, 1990, https://doi.org/10.2307/762172.

41 Nurhidayatuloh et. al., "Does Limitation Rule in International and Regional Human Rights Law Instruments Restrict Its Implementation?," International Journal of Recent Technology and Engineering 8, no. 2S9 (2019): 597-600, https://doi.org/10.35940/ijrte.B1125.0982S919.

42 Cohen.

43 United Nations, "United Nations General Assembly Resolution 44/236," in 85th Plenary Meeting, 1989.

44 United Nations.

45 “Williams v Williams,” Victorian Reports, 1965, https://doi.org/10.25291/vr/1966-vr-60. 
1999 as amended. ${ }^{46}$ The Act gives legal effect to the commitment made by Nigeria under the UNCRC, and the AUCRWC. This law was passed at the Federal level. The Child Rights Act was created to serve as legal documentation and protect children's rights and responsibilities in Nigeria. ${ }^{47}$ Before enacting the CRA, the primary law dealing with matters affecting children in Nigeria was the Children and Young Person's Act (CYPA 1958) and the Labour Act 2004. The structure of the CRA has shown that there is a mandate to provide a legislation that will incorporate all the rights and responsibilities of children which consolidates all laws relating to children into one single legislation as well as specifying the duties and obligations of government, parents, authorities, organizations and other related bodies to children.

Some notable decided cases in Nigeria to buttress the extent of implementation of child rights can be seen in the case of Otti v $\mathrm{Otti}^{48}$ where it was held that the responsibilities of parents to children entails the inherent responsibility to control, preserve and care for the child's person, food, clothing, e.t.c, similar decision was held in the case of Alabiv Alabi.

The delay by some States in Nigeria to adopt the Child Rights Act or to enact a replica of CRA has been described as a great hindrance to the development and protection of the Nigerian child by the United Nations Children Fund (UNICEF) Chief of Bauchi Field Office, Mr. Bhanu Pathak in a speech during the 2018 Children's Day Celebrations at UNICEF office in Bauchi (Nigeria). ${ }^{49}$ Mr. Pathak emphasized that States are reluctant to adopt the Act for onward implementation despite the Federal Governments effort. He restated his expectations that he desires to see that all States of the federation have signed the law for implementation. ${ }^{50}$ Despite that some Nigerian states have enacted the CRA, there still exists the problem of full implementation and full enforcement. Geoffery asserted that most States that have assented to the law appear reluctant to enforce it because they believe that it would make children grow wild and this is not true as he added. ${ }^{51}$ This misconception is also at the root of the reluctance to pass the bill in the few states yet to implement the CRA. ${ }^{52}$

\section{The Enforceability of International Law under the Nigerian Legal System}

The Nigerian constitution provides in Section 12 that "no treaty between the Federation and any other country shall have the force of law except to the extent to which any such treaty has been enacted into law by the National Assembly". The status of International law in Nigeria solely relies on this provision. Furthermore, customary international law can be Judicially Noticed as seen in the case of African Continental Bank v Eagles Super Pack Ltd ${ }^{53}$ and Section 17 of the Evidence Act, 2011 even though such laws are not enacted in the state.

\footnotetext{
46 Olusola Babatunde Adegbite, Oreoluwa Omotayo Oduniyi, and Jubril Akinwunmi Farinde, "Separation of Powers Under the 1999 Nigerian Constitution: The Core Legal Dilemmas," Sriwijaya Law Review 3, no. 2 (2019): 235-52, https://doi.org/10.28946/slrev.Vol3.Iss2.281.pp235-252.

47 Stephen N Achilihu, A Comparative and Legal Analysis of the United Nations Convention on the Rights of the Child (Universal-Publishers, 2010).

48 Yusuf Ali \& Co, "Nigeria Weekly Law Report," 1992.

49 Balarabe Alkassim, "Non-Domestication of Child Rights Act by States Worrying," UNICEF, 2018, https://www.dailytrust.com.ng/non-domestication-of-child-rights-act-by-States-worrying-says-unicef.html.

50 Balarabe Alkassim.

51 Yusuf Ali \& Co, "Nigeria Weekly Law Report."

52 Yusuf Ali \& Co.

53 Yusuf Ali \& Co.
} 
In the case of African Continental Bank $v$ Eagles Super Pack Ltd, ${ }^{54}$ the issue for determination was whether the Uniform Custom and Practice (UCP) for documentary credit is applicable in Nigeria. The International Chamber made the UCP of Commerce with its headquarters in Paris with a view of having a universal standardization of letters of credit in banking and commercial transactions. At the trial court, Per Ononuju $\mathbf{J}$ held that the UCP is not applicable in Nigeria. However, it was held at the Court of Appeal that the UCP constitutes customary international law and can be judicially noticed and applied in Nigeria. ${ }^{55}$

From the provision of section 17 of the Evidence Act, 2011, it is clear that an International Law, although not ratified in Nigeria, shall have the force of law in Nigeria if it has been adjudicated upon by a superior court of record. A visible example is the boundary case between Nigeria $v$ Cameroon (Supra). By implication, laws established there from becomes binding on Nigeria even though Nigeria has not ratified such law.

\section{Responsible Factors for the Full Implementation Failure of the UNCRC and the CRA}

The success of the enactment of the Childs Right Act 2003 is as a result of the signing and ratification of the UNCRC and the AUCRWC. The CRA serves as a necessary legal backup to the commitment made by Nigeria to the UNCRC and the AUCRWC by Nigeria.

All issues concerning a child in Nigeria before 1993 was handled by the Department of Social Welfare of the Federal Ministry of Social Development Culture. After the Children Summit in 1990, a Commission was created which has now been divided into two, i.e. the Ministry of Women Affairs and Youth Development to take over issues relating to children. In 1994, the Federation's Government inaugurated the National Child Rights Implementation Committee (NCRIC) to popularize the AUCRWC and the UNCRC. The body enhanced the signing and ratification of the two optional protocols of the UNCRC, which eventually led to the CRA's enactment. ${ }^{56}$ Hence the enactment of the CRA by the Federal Government of Nigeria, responsibility was placed on the NCRIC to ensure full implementation of the CRA in all states of the federation. Other bodies sharing this responsibility include the National Human Rights Commission (NHRC), ${ }^{57}$ National Agency for the Prohibition of Trafficking in Persons (NAPTIP), ${ }^{58}$ and among others.

The Government of Nigeria has taken steps to ensure compliance and enforcement of the UNCRC, AUCRWC and CRA. However, there are no significant records of enforcement, especially in States that are yet to enact the CRA. ${ }^{59}$

54 Yusuf Ali \& Co.

55 Azoro, "The Place of Customary International Law in the Nigerian Legal System-A Jurisprudential Perspective."

56 The two protocols include the Optional Protocol to the Convention relating to the Rights of the Child on Children's involvement in Armed Conflict and the Protocol Concerning the Sale of Children, the Prostitution of Children and Pornography Exhibiting Children.

57 A commission established in 1995 under NHRC Act as amended in 2010 to serves as machinery for safeguards of the Human Rights of the Nigerian Population. It monitors Human Rights in Nigeria, assists victims of human rights violations, and helps formulate the Nigerian governments' policies on human rights.

58 The NAPTIP is an agency of the government to combat human trafficking and other similar human rights violations. It was created in 2003. NAPTIP is one of the agencies under the supervision of the Federal Ministry of Justice.

59 Despite it being signed as an Act of the National Assembly it becomes binding automatically on the FCT and any other state that ratifies the same. Therefore, the scope of the application and enforceability of the Act or Law 
One of the factors responsible for the problem of non or poor implementation of the CRA is the attitude of Nigerian courts to International laws or treaties adopted for implementation in Nigeria. In Ogugu $v$ State $^{60}$ the Supreme Court of Nigeria held that the African Charter provisions are enforceable but through the Nigerian courts' already existing rules and procedures. In Chief Gani Fawehinmi v Sani Abacha ${ }^{61}$ the Supreme Court stated that the African Charter is below the constitution, and in cases of clash of conflicts, the constitution shall prevail. The combined effect of the above two cases implies that International law shall be subjected to the Nigerian court's rules and proceedings. If there are inconsistencies between International law and the constitution of Nigeria, the constitution shall prevail.

Secondly, the federal system of government in Nigeria impedes the full implementation of the Child Rights Act 2003. Each of the thirty-six States of the federation is autonomous and equal to each other. ${ }^{62}$ These 36 States have their own Houses of Assembly saddled with the responsibilities of making local laws suitable to the people of the state. Where the National Assembly makes a law, it becomes binding and enforceable in Nigeria as it is a federal law and for such law to be binding on a State, the state must enact that law as a State law. The above practice means that States will have two similar laws applicable, i.e. the federal law and the State law. These two laws bring about contention as to which is to be enforced where there is a breach. It is important to note that the law enforcement agents in Nigeria operate as federal agencies. Invariably, the federal law is what they enforce. Who then enforce the State laws? What is the essence of State law?

The customs and traditions of individual societies/ states also contribute to the nonimplementation or partial implementation of the CRA in some states in Nigeria. Obviously, some states' customs and practices in Nigeria, especially those of rural areas, conflict with the CRA.

These customs and practices range and vary among the people/ society inhabiting Nigeria cutting across the North, East, West and South of Nigeria. These practices include marrying off girls before they attain the age of 18, killing of twins' and albinos, discrimination against children with disabilities, future promises of marriage made on behalf of young children, unnecessary and severe labour on children especially on orphans and children living with guardians, female genital mutilation e.t.c. All the above mentioned customary practices are in contravention of the provisions of the Child Rights Act. Some of the provisions of the Child Rights Act contravened include sections 1 (Best interest of a child), section 4 (Right to survival and development), section 10 (no deprivation merely because of the circumstance of birth), section 11 (Right to dignity, i.e. no physical, mental, emotional injury or abuse, neglect or maltreatment including sexual abuse on a child), section 21 (prohibition against marriage under 18 years. Such marriage is null and void), section 22 (No betrothal of young girls for future marriage), section 25 (exposure of children to trafficking of narcotic drugs), use of children in other criminal activities, section 28 (prohibition of exploitative labour i.e. no child should work except in the family and agricultural work heavy to adversely affect physical, mental, spiritual, moral or social

as the case may be is restricted to being applied in FCT and any State which consent to its application and enforcement through ratification.

60 Yusuf Ali \& Co, "Nigeria Weekly Law Report."

61 Yusuf Ali \& Co.

62 B.N. Garner, The Black's Law Dictionary. 
development) and section 32 (other forms of exploitation of a child) which is an omnibus provision for the protection of a Child. ${ }^{63}$

It is pertinent to mention that people consider their customary practices sacred and complicated for such people to abolish such custom.

Furthermore, some States have deliberately refused to enact or replicate CRA. This could be due to several reasons peculiar to the States that have refused to enact the law. On the other hand, some other States have replicated the CRA but refused to fully implement the law. ${ }^{64}$ More so, there is also the notion that the CRA gives so much liberty to children because it dispenses the standard African style for the discipline of Children which may be regarded as a breach of Children's Right by the CRA. The African culture believes and relies so much on beating as a means of disciplining a child. To beat a child is the same as correcting the child. The Child Rights Act frowns at any act of battery, torture, suffering or inhumane Act to a child. It invariably amounts to a conflict between the Child Rights Act and the African system of a child's discipline. With this African perception, adoption, and full implementation of the CRA would be practically impossible because the Act would establish restrictions to the African system of discipline.

\section{CONCLUSION}

Conclusively, laws are made to be obeyed. Invariably, there will be no need to make laws if there is no possibility of implementation and enforcement. The UNCRC and CRA are both innovative landmark laws made for the protection of children specifically. It is worthy of note that these laws are specifically enacted to protect the best interest of a child. The child's interest cannot be overemphasized; hence, these instruments are needed in every State of Nigeria. Adoption, enactment, implementation, and enforcement of the CRA imply growth and development and, most importantly, honour and respect for children's life and existence.

However, many factors have contributed to the problem of full implementation and full enforcement. Most notably is the federal system of government which is being practised in Nigeria. The dual system of law-making also contributes to this problem. Due to CRA's importance, States are therefore enjoined to enact or replicate CRA and ensure full implementation of the same. Even as there is no international law enforcement agency, it is the state's responsibility to ensure enforcement.

From the findings and discussions, this paper recommends as follow: 1) Adequate awareness should be created provided by the government agencies, NGOs, and social organizations handling issues of the child in States that are yet to attain full implementation of the Act on the innovations brought by the Child Rights Act to enhance the wellbeing of the Children; 2) Proper steps or protocols should be put in place for law enforcement agencies to ensure successful implementation and full enforcement of the Child Rights Act in the best interest of children; 3) It is further recommended that having an International Law enforcement agency will also assist in ensuring that nations or States that have signed the International Law or Treaty to comply with same. Such agencies should be given the power to investigate and recommend cases to

63 "Child Rights Act 2003" (n.d.).

${ }^{64}$ Yusuf Ali \& Co, "Nigeria Weekly Law Report." 
appropriate authorities for prosecution of violators; 4) National and State Houses of Assemblies must ensure that International laws are not just adopted, signed, ratified and domesticated. They should endeavor to give such laws adequate considerations and scrutiny with the sole aim of having better laws in the society through the instrumentality of States rights of reservation and the open right to amend laws to suit a State's peculiar condition; 5) Additionally, National and State Houses of Assemblies must endeavor to sign and ratify International laws in which enforceability is achievable so as not to have dormant laws in the state.

\section{REFERENCES}

Achilihu, Stephen N. A Comparative and Legal Analysis of the United Nations Convention on the Rights of the Child. Universal-Publishers, 2010.

Adegbite, Olusola Babatunde, Oreoluwa Omotayo Oduniyi, and Jubril Akinwunmi Farinde. "Separation of Powers Under the 1999 Nigerian Constitution: The Core Legal Dilemmas." $\begin{array}{lllllll}\text { Sriwijaya Law Review 3, no. } 235-52 . & \end{array}$ https://doi.org/10.28946/slrev.Vol3.Iss2.281.pp235-252.

Anushiem, C.E. Okeke and M.I. "Implementation of Treaties in Nigeria: Issues, Challenges and the Way Forward." Nnamdi Azikiwe University Journal of Internastional Law and Jurisprudence 9, no. 217 (2018).

Aust, Anthony. Domestication of International Law Modern Treaty Law and Practice. Cambridge University Press, 2019.

Azoro, C. J. S. "The Place of Customary International Law in the Nigerian Legal System-A Jurisprudential Perspective." International Journal of Research (IJR) 1, no. 3 (2020).

B.N. Garner. The Black's Law Dictionary. 8th ed. West Group, St Paul MINN, 2004.

Balarabe Alkassim. "Non-Domestication of Child Rights Act by States Worrying." UNICEF, 2018. https://www.dailytrust.com.ng/non-domestication-of-child-rights-act-by-Statesworrying-says-unicef.html.

"Cameroon v Nigeria 2002 ICJ Reports (Boundary Dispute between Cameroon and Nigeria on Land and Maritime)," n.d.

Child Rights Act 2003 (n.d.).

Clarendon Pres, Oxford, and United Nations Treaty Collection, Treaty Reference Guide. Definition of Key Terms, 1999. http://untreaty.un.org/guide/asp.

Cohen, Cynthia Price. "The Role of Nongovernmental Organizations in the Drafting of the Convention on the Rights of the Child." Human Rights Quarterly, 1990. https://doi.org/10.2307/762172.

D. D Caron. "Land and Maritime Boundary between Cameroon and Nigeria 2002." American Journal of International Law, n.d. http://www.icj-cj.org.

Ese Malemi. Nigerian Legal System. 3rd ed., 1999.

EU Law Glossary. When a Dualist State Signs a Treaty, the Treaty Becomes Binding Only If It Is Incorporated by a Domestic Statute. Oxford University Press, 2008.

F, Daniels. A. "Historical Survey of Amalgamation of the Northern and Southern Police Departments of Nigeria in 1930." European Scientific Journal 8, no. 18 (2011).

Hannum, Hurst. "The UDHR in National and International Law." JSTOR 3, no. 2 (1998): 14458. 
Legal, US. "Legal System Law and Legal Definition.” uslegal.com, 2019.

Nike Adebowale. "Why Every State in Nigeria Must Adopt and Implement the Childs Rights Act," n.d. https://allafrica.com/stories/201906250022.html.

Nurhidayatuloh et. al. "Does Limitation Rule in International and Regional Human Rights Law Instruments Restrict Its Implementation?" International Journal of Recent Technology and Engineering 8, no. 2S9 (2019): 597-600. https://doi.org/10.35940/ijrte.B1125.0982S919.

Okpalaobi \& Ekwueme. United Nations Convention on the Rights of a Child: Implementation of Legal and Administrative Measure in Nigeria. NAUJILI, 2015.

Oladiji, Geofrey Njoku and Sharon. "Calling on 15 States Left to Protect Their Children." Allafrica, 2009.

O A. Hathaway "Do Human Rights Treaties Make a Difference?", The Yale Journal Vol. 111, No. 8 (Jun., 2002, pp. 1935-2042 (108 Pages) (The Yale Law Journal Company, Inc.) https://doi.org/10.2307/797642

Tobi N. Sources of Nigerian Law. Edited by U S Abbo and Others Umar Alkali. Internatio (Lagos: M.J. Professional Publishers Ltd, 1996.

Umar Alkali, U S Abbo and Others. "Nature and Sources of Nigerian Legal System: An Exorcism of a Wrong Notion." International Journal of Economics, Law and Business 5, no. 4 (2014): 1-10.

UN WOMEN. "Overview and International Legal Instruments," 2020. www.endvawnow.org/en/articles/582-overview-and-international-legal-instruments.html.

United Nations. "United Nations General Assembly Resolution 44/236." In 85th Plenary Meeting, 1989.

United Nations Convention on the Rights of a Child 1989 Part 1 Art 1 (n.d.).

“WILLIAMS v WILLIAMS.” Victorian Reports, 1965. https://doi.org/10.25291/vr/1966-vr-60.

Find Law. 2016 What is International Law. Available from: https://www.findlaw.com/hirealawyer/international-law.html [retrieved: December 24, 2020 at 18:07]

Iceladic Human Rights Centre. International Law Instruments. Available from: https://www.humanrights.is/en/human-rights-education-project/human-rightsinstruments/internationational-law-instruments [retrieved: October 02, 2019 at 22:15]

Premium Times 2019. Why every Nigerian state must domesticate, implement Child Rights Act. Available from: https://www.premiumtimesng.com/health/health-features/336790- whyevery-nigerian-state-must-domesticate-implement-child-rights-act.html [retrieved: December 23, 2020]The 1969 Vienna Convention on the Law of Treaties, Article 2 (1) (b) (n.d.).

Unicef. The 1989 United Nations Convention on the Rights of a Child. Available from: https://www.unicef.org/child-rights-convention/what -is-the-convention [retrieved: December 24, 2020 at 09:13 am]

Yusuf Ali \& Co. "Nigeria Weekly Law Report," 1992. 